\title{
Biological and genetic aspects of crosses between species of the genus Meccus (Hemiptera: Reduviidae Triatominae)
}

\author{
José Alejandro Martínez-Ibarra1/+, Yunuen Grant-Guillén', Luz Verónica Ventura-Rodríguez', \\ Paola Denisse Osorio-Pelayo', Michael Dassaejv Macías-Amezcua', Karla Meillón-Isáis', \\ Ricardo Alejandre-Aguilar², Elvia Rodríguez-Bataz ${ }^{3}$, Benjamín Nogueda-Torres ${ }^{2}$
}

ª́rea de Entomología Médica, Centro Universitario del Sur, Universidad de Guadalajara, AP 20, 49000 Ciudad Guzmán, Jalisco, México
${ }^{2}$ Escuela Nacional de Ciencias Biológicas, Instituto Politécnico Nacional, Colonia Casco de Santo Tomás, México DF, México
${ }^{3}$ Unidad Académica de Desarrollo Regional, Universidad Autónoma de Guerrero, Chilpancingo, Guerrero, México

The degree of reproductive isolation between Meccus phyllosomus and the remaining five species of the genus Meccus, as well as between Meccus bassolsae and Meccus pallidipennis, Meccus longipennis and Meccus picturatus, was examined. Fertility and the segregation of morphological characteristics were examined in two generations of hybrids from crosses between these species. The percentage of couples with offspring (fertile) was high in the vast majority of sets of crosses, with the exception of that between $9 \mathrm{M}$. phyllosomus and ${ }^{7}$ Meccus mazzottii. In sets of crosses involving M. bassolsae specimens, no first-generation (F1) individuals were morphologically similar to M. bassolsae, but instead shared the morphology of the other parental species. A similar phenomenon was observed in most sets of crosses involving M. phyllosomus. These results indicated that different degrees of reproductive isolation exist among the species of Meccus involved in this study. The biological evidence obtained in this study does not support the proposal that $\mathrm{M}$. bassolsae is a full species. It could indicate that, on the contrary, it should be considered a subspecies of a single polytypic species. The biological evidence does support the proposal that M. phyllosomus is a full species.

Key words: Phyllosoma complex species - reproductive isolation - hybrids - phylogenetic level

In Mexico, the six species of the Phyllosoma complex included in the genus Meccus - Meccus pallidipennis (Stål), Meccus longipennis (Usinger), Meccus picturatus (Usinger), Meccus mazzottii (Usinger), Meccus bassolsae (Alejandre-Aguilar, Nogueda-Torres, CortésJiménez, Jurberg, Galvão and Carcavallo) and Meccus phyllosomus (Burmeister), plus Triatoma mexicana (Herrich-Schaeffer) - play a major role in the transmission of Trypanosoma cruzi to human populations. They are commonly found in both domestic and wild ecotopes and often have high values in entomological indexes (Martínez-Ibarra et al. 2008a, 2010, Licón-Trillo et al. 2010, Medina-Torres et al. 2010, Rodríguez-Bataz et al. 2011). A discussion regarding the proper taxonomic assignment of these species of the genus Meccus (species or subspecies) has been ongoing for a number of years (Mazzotti \& Osorio 1942, Lent \& Wygodzinsky 1979). Biological and molecular studies on typical specimens (Mazzotti \& Osorio 1942, Martínez et al. 2006, Bargues et al. 2008, Martínez-Ibarra et al. 2008b) and on the naturally crossbred descendents of different individuals from sympatric populations (M. pallidipennis, $M$. longipennis and $M$. picturatus) (Martínez-Ibarra et al. 2009, Martínez et al. 2010) have lead to a proposal to re-

+ Corresponding author: aibarra@cusur.udg.mx

Received 11 September 2010

Accepted 14 January 2011 classify some (M. pallidipennis, M. longipennis and M. picturatus) (Marcilla et al. 2001, Martínez-Ibarra et al. 2008b) or all (Bargues et al. 2008, Martínez et al. 2010) of the six species of the genus Meccus to subspecies of M. phyllosomus. Other molecular and biological studies support the consideration of these groups as full species (Sainz et al. 2004, Pfeiler et al. 2006, Martínez-Ibarra et al. 2008b). However, molecular evidence (Bargues et al. 2008) supports the revalidation of the genus Meccus for the six species traditionally grouped into the Phyllosoma complex (Carcavallo et al. 2000).

Previous studies have estimated the degree of reproductive isolation among four of these species (M. pallidipennis, M. longipennis, M. picturatus and M. mazzottii) (Mazzotti \& Osorio 1942, Martínez-Ibarra et al. 2008b, 2009); however the degree of isolation remains unknown between the remaining species. Therefore, this study was conducted to investigate reproductive isolation among the six species of Meccus, with the aims of broadening our understanding of this phenomenon and gathering additional information about both the degree of closeness among them and the appropriate level for their taxonomical assignment.

\section{MATERIALS AND METHODS}

Crosses between species from non-overlapping areas under laboratory conditions - Specimens used in these crosses were obtained from colonies established for at least six generations with Triatominae from nonoverlapping areas. This was done to ensure the purity of the colonies with regard to the exclusion of previous interfertility events. The six colonies used in the experi- 
ments encompassed the six species of Meccus. Colonies were started for each species as follows: M. pallidipennis, 30 specimens collected in Amilzingo, Morelos (18 ${ }^{\circ} 50^{\prime} \mathrm{N}$ $\left.98^{\circ} 49^{\prime} \mathrm{W}\right)$; M. longipennis, 95 specimens collected in Salamanca, Guanajuato $\left(20^{\circ} 46^{\prime} \mathrm{N} 101^{\circ} 15^{\prime} \mathrm{W}\right)$; M. picturatus, 43 specimens from Jala, Nayarit $\left(21^{\circ} 03^{\prime} \mathrm{N} 104^{\circ} 26^{\prime} \mathrm{W}\right)$; M. mazzottii, 18 specimens collected in Jocutla, Guerrero $\left(17^{\circ} 26^{\prime} \mathrm{N} 99^{\circ} 16^{\prime} \mathrm{W}\right) ;$ M. bassolsae, 20 specimens from Acatlán, Puebla $\left(18^{\circ} 10^{\prime} \mathrm{N} 96^{\circ} 06^{\prime} \mathrm{W}\right)$ and M. phyllosomus, 12 specimens from Tehuantepec, Oaxaca $\left(16^{\circ} 28^{\prime} \mathrm{N}\right.$ $\left.95^{\circ} 19^{\prime} \mathrm{W}\right)$. The only overlapping species of Triatominae (when one was present) was Triatoma barberi Usinger, a smaller species, and in this case size differences were considered sufficient to prevent its crossing with other species in the complex. The collected specimens were identified using the Lent and Wygodzinsky (1979) keys and exhibited the typical morphological characteristics of each former species.

Meccus phyllosomus was crossed with the other five species of Meccus, whereas M. bassolsae was crossed with three species, M. pallidipennis, M. longipennis and M. picturatus, following methodology (Martínez-Ibarra et al. 2008b, 2009) previously established for crosses involving the relevant species. For those crosses, 10 couples from each set were placed in plastic jars $(5 \mathrm{~cm}$ diameter x $10 \mathrm{~cm}$ height), as indicated in Table I. The developmental cycle of each parental lineage involved in the study was used as a control; most of these data

TABLE I

Percentages of successful (offspring-producing) crosses between the species of the genus Meccus under laboratory conditions

\begin{tabular}{|c|c|c|c|}
\hline Crosses & $\begin{array}{l}\text { Successful parental } \\
\text { crosses } \\
(\%)\end{array}$ & $\begin{array}{c}\text { F1 vs. F1 crosses. } \\
\text { Phenotypes of parental } \\
\text { F1 crosses }\end{array}$ & $\begin{array}{l}\text { Successful } \\
\text { F1 vs. F1 crosses } \\
(\%)\end{array}$ \\
\hline $\begin{array}{l}+M . \text { phyllosomus } x \\
\delta^{\top} M . \text { pallidipennis }\end{array}$ & 100 & $\begin{array}{l}+M \cdot \text { pallidipennis } x \\
\widehat{\partial} M . \text { pallidipennis }\end{array}$ & 0 \\
\hline $\begin{array}{l}+M . \text { pallidipennis } x \\
\delta^{\top} M . \text { phyllosomus }\end{array}$ & 100 & 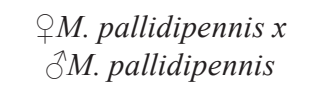 & 0 \\
\hline $\begin{array}{l}+M . \text { phyllosomus } x \\
\jmath^{\top} M . \text { longipennis }\end{array}$ & 100 & $\begin{array}{l}\text { } M . \text { longipennis } x \\
\curvearrowright M . \text { longipennis }\end{array}$ & 8 \\
\hline $\begin{array}{l}\text { } M . \text { longipennis } x \\
\partial^{\lambda} M . \text { phyllosomus }\end{array}$ & 100 & $\begin{array}{l}+M . \text { longipennis } x \\
\curvearrowright M . \text { longipennis }\end{array}$ & 12 \\
\hline $\begin{array}{l}+M . \text { phyllosomus } x \\
\delta^{\top} M . \text { picturatus }\end{array}$ & 100 & $\begin{array}{l}\text { } M \cdot \text { picturatus } x \\
\delta^{\lambda} \cdot \text { picturatus }\end{array}$ & 44 \\
\hline $\begin{array}{l}q M \cdot \text { picturatus } x \\
\text { TM. phyllosomus }\end{array}$ & 70 & $\begin{array}{l}+M \cdot \text { picturatus } x \\
\rceil_{M} \text { picturatus }\end{array}$ & 25.7 \\
\hline $\begin{array}{l}\text { } M . \text { phyllosomus } x \\
\delta^{\lambda} M . \text { mazzottii }\end{array}$ & 30 & $\begin{array}{l}\text { }+M . \text { mazzottiix } \\
\delta^{\top} M . \text { mazzottii }\end{array}$ & 53.3 \\
\hline $\begin{array}{l}q M . \text { mazzottiix } \\
\jmath^{\lambda} M \cdot \text { phyllosomus }\end{array}$ & 100 & $\begin{array}{l}+M \cdot \text { mazzottiix } \\
\overbrace{}^{\top} M . \text { mazzottii }\end{array}$ & 50 \\
\hline $\begin{array}{l}\text { } M . \text { phyllosomus } x \\
{ }^{\top} M . \text { bassolsae }\end{array}$ & 100 & $\begin{array}{l}\text { } 9 \text { M. phyllosomus } x \\
\precsim M \cdot \text { phyllosomus }\end{array}$ & 0 \\
\hline $\begin{array}{l}q M . \text { bassolsae } x \\
\lambda^{\top} \text {. phyllosomus }\end{array}$ & 100 & $\begin{array}{l}\text { }+M \cdot \text { phyllosomus } x \\
\widehat{\jmath} \text {. phyllosomus }\end{array}$ & 0 \\
\hline $\begin{array}{l}+M . \text { bassolsae } x \\
\lambda M . \text { pallidipennis }\end{array}$ & 90 & $\begin{array}{l}\text { } 9 \text { M. pallidipennis } x \\
\widehat{\partial} \text { M. pallidipennis }\end{array}$ & 97.8 \\
\hline $\begin{array}{l}+M . \text { pallidipennis } x \\
\uparrow^{\top} M . \text { bassolsae }\end{array}$ & 100 & $\begin{array}{l}+M \cdot \text { pallidipennis } x \\
\widehat{\partial} \text {. pallidipennis }\end{array}$ & 28 \\
\hline $\begin{array}{l}+M . \text { bassolsae } x \\
\uparrow M . \text { longipennis }\end{array}$ & 80 & $\begin{array}{l}+M . \text { longipennis } x \\
\widehat{\jmath} \text { M. longipennis }\end{array}$ & 85 \\
\hline $\begin{array}{l}+M . \text { longipennis } x \\
\tau^{\top} M . \text { bassolsae }\end{array}$ & 80 & $\begin{array}{l}\text { } M \text { M. longipennis } x \\
\jmath^{\lambda} \text {. longipennis }\end{array}$ & 75 \\
\hline $\begin{array}{l}q M . \text { bassolsae } x \\
\hat{\sigma}^{\top} M . \text { picturatus }\end{array}$ & 100 & $\begin{array}{l}+M \cdot \text { picturatus } x \\
\overbrace{}^{\lambda} \cdot \text { picturatus }\end{array}$ & 98 \\
\hline $\begin{array}{l}+M . \text { picturatus } x \\
\jmath^{\top} M . \text { bassolsae }\end{array}$ & 100 & $\begin{array}{l}+M \cdot \text { picturatus } x \\
\supset M \cdot \text { picturatus }\end{array}$ & 100 \\
\hline
\end{tabular}


have been previously published (Martínez-Ibarra et al. 2003a, b, 2006, Martínez-Ibarra \& Novelo-López 2004). Specimens were maintained in incubators at $27 \pm 1^{\circ} \mathrm{C}$ with $75 \pm 5 \%$ relative humidity and were fed weekly on New Zealand rabbits.

To record fecundity, all crosses were checked daily for spermatophore eliminations and copulation events. To check egg fertility, eggs from each cross were collected for 25 days and incubated under previously described laboratory conditions. A total of 30 first instar nymphs from each of the 20 crosses for each set were placed in plastic jars (10 in each jar). These specimens were fed on rabbit blood and reared. In order to prevent uncontrolled matings, the first 20 nymphs to reach the fifth instar were sexed and females were separated from males into fresh plastic jars until they reached the adult stage.

In those cases where crosses were unsuccessful, males were co-incubated with a virgin female of their parental lineage, while females were co-incubated with a parental male. The fertility of all studied adults was confirmed when the females laid numerous fertile eggs resulting in first instar nymphs.

Crosses between F1 individuals - To determine whether the F1 offspring of crosses between the six species in the study were fertile, five F1 females and five sibling F1 males were crossed. When the F2 generation had been obtained, segregation of phenotypes, viability and fertility were determined. Again, with the aim of gathering at least 20 adults, given mortality rates, 30 first instar nymphs from each of the crosses from each set were placed in plastic jars (10 in each jar). Nymphs were fed on rabbit blood and reared to adulthood. Next, the phenotype of the offspring of each couple was described. Likewise, to ascertain the fertility of the F2 generation, five F2 females and five sibling F2 males were crossed. F2 fertility was confirmed by the presence of first instar nymphs, after which the progeny were not further characterised.

In order to ascertain whether male or female specimens involved in F1 x F1 crosses that produced no F2 progeny were fertile, F1 progeny were backcrossed with specimens of the morphologically dominant parental lineage (Southwood \& Henderson 2000). If no offspring were obtained, the F1 progeny were backcrossed with specimens of the other parental lineage. In both cases, the fertility of all studied adults was confirmed when the females laid numerous fertile eggs and produced first instar nymphs.

\section{RESULTS}

The success rate (couples with offspring) was $100 \%$ in most parental crosses. The highest success rates were obtained in crosses between M. phyllosomus and M. pallidipennis, M. longipennis and M. bassolsae and between $M$. picturatus and M. bassolsae and the lowest were in those between an M. mazzottii male and an M. phyllosomus female. However, the success rate in F1 x F1 crosses was higher in crosses between M. bassolsae and M. longipennis and M. picturatus (in both directions) and in crosses between ${ }^{\prime} M$. bassolsae and $\widehat{\jmath} M$. pallidipennis. The lowest success rates were in crosses between M. phyllosomus and M. pallidipennis and M. bassolsae (Table I).
The morphological characteristics listed in the keys (pronotum with humeral angles rounded, length more than $25 \mathrm{~mm}$, strongly widened abdomen, pilosity abundant, first antennal segment attaining or surpassing level of apex of clypeus, spongy fossulae absent in both sexes) were present in all F1 specimens.

Additionally, F1 specimens had specific morphological characteristics leading us to distinguish between them as follows:

Phenotypes of Fl offspring of crosses between M. phyllosomus and M. pallidipennis - All F1 individuals were morphologically similar to M. pallidipennis (Table II).

\section{TABLE II}

Main characteristic phenotypes of the first generation (F1) inherited from crosses between species of the genus Meccus under laboratory conditions

\begin{tabular}{|c|c|c|c|c|c|c|c|c|c|c|}
\hline \multirow[b]{2}{*}{ Crosses } & \multicolumn{2}{|c|}{$\mathrm{Mp}$} & \multicolumn{2}{|c|}{ Ml } & \multicolumn{2}{|c|}{ Mpi } & \multicolumn{2}{|c|}{$\mathrm{Mm}$} & \multicolumn{2}{|c|}{ Mph } \\
\hline & q & $\hat{\sigma}$ & ㅇ & $\hat{o}$ & $q$ & $\hat{o}$ & 우 & $\hat{\sigma}$ & 우 & $\hat{0}$ \\
\hline $\begin{array}{l}\text { +M. phyllosomus } x \\
\curvearrowright M . \text { pallidipennis }\end{array}$ & 104 & 96 & - & - & - & - & - & - & - & - \\
\hline \begin{tabular}{l} 
9 . pallidipennis $x$ \\
\multirow{\lambda}{\top}{. phyllosomus }
\end{tabular} & 99 & 101 & - & - & - & - & - & - & - & - \\
\hline $\begin{array}{l}\text { +M. phyllosomus } x \\
{ }^{\top} M . \text { longipennis }\end{array}$ & - & - & 91 & 109 & - & - & - & - & - & - \\
\hline $\begin{array}{l}\text { †M. phyllosomus } x \\
{ }^{\top} M \cdot \text { picturatus }\end{array}$ & - & - & - & - & 111 & 89 & - & - & - & - \\
\hline $\begin{array}{l}+M \cdot \text { picturatus } x \\
\text { ऽM. phyllosomus }\end{array}$ & - & - & - & - & 95 & 45 & - & - & - & - \\
\hline $\begin{array}{l}\text { } 9 \text {. phyllosomus } x \\
\delta^{\prime} M . \text { mazzottii }\end{array}$ & - & - & - & - & - & - & 27 & 33 & - & - \\
\hline $\begin{array}{l}\text { oM. mazzottii } x \\
\jmath^{\top} M \cdot \text { phyllosomus }\end{array}$ & - & - & - & - & - & - & 107 & 93 & - & - \\
\hline $\begin{array}{l}\text { oM. phyllosomus } x \\
\text { TM. bassolsae }\end{array}$ & - & - & - & - & - & - & - & - & 102 & 98 \\
\hline $\begin{array}{l}\text { oM. bassolsae } x \\
\jmath^{\lambda} . \text { phyllosomus }\end{array}$ & - & - & - & - & - & - & - & - & 104 & 96 \\
\hline \begin{tabular}{l}
$+M$. bassolsae $x$ \\
\multirow{\lambda}{\top}{. pallidipennis }
\end{tabular} & 62 & 118 & - & - & - & - & - & - & - & - \\
\hline $\begin{array}{l}+M . \text { pallidipennis } x \\
\jmath^{\prime} M . \text { bassolsae }\end{array}$ & 124 & 76 & - & - & - & - & - & - & - & - \\
\hline $\begin{array}{l}+M . \text { bassolsae } x \\
\rceil^{\top} M . \text { longipennis }\end{array}$ & - & - & 78 & 82 & - & - & - & - & - & - \\
\hline $\begin{array}{l}+M . \text { longipennis } x \\
\partial^{\top} M . \text { bassolsae }\end{array}$ & - & - & 87 & 73 & - & - & - & - & - & - \\
\hline $\begin{array}{l}+M . \text { bassolsae } x \\
\uparrow M . \text { picturatus }\end{array}$ & - & - & - & - & 102 & 98 & - & - & - & - \\
\hline $\begin{array}{l}\text { oM. picturatus } x \\
\delta^{\lambda} \text {. bassolsae }\end{array}$ & - & - & - & - & 94 & 106 & - & - & - & - \\
\hline
\end{tabular}

M1: Meccus longipennis; Mm: Meccus mazzottii; Mp: Meccus pallidipennis; Mph: Meccus phyllosomus; Mpi: Meccus picturatus. 
Phenotypes of F2 offspring of crosses between $M$. phyllosomus and M. pallidipennis - No F2 specimen was obtained (Table III). To determine whether F1 adults were fertile, they were individually backcrossed with adults from the M. pallidipennis parental lineage. All F1 females thus tested laid fertile eggs, from which numerous first instar nymphs were obtained. However, although numerous mating events and spermatophore eliminations by females were observed when F1 male specimens were crossed with virgin females of M. pallidipennis, the resulting eggs were infertile. To complement this analysis, virgin females of the other parental lineage (M. phyllosomus) were individually co-incubated with each male being tested. Once again, although copulative events and spermatophore eliminations were recorded in all couples, the resulting eggs were infertile. To confirm that all F1 males were infertile, all females used in the fertility test were crossed with parental lineage males. Fertile eggs, as well as first instar nymphs, were obtained and the apparent infertility of male hybrids was confirmed.

Non-morphological hybrids of M. phyllosomus and M. pallidipennis - These hybrids presented with a corium that was primarily yellowish white, with narrow orange bands at the base and black at the apex (similar to M. pallidipennis) (Fig. 2).

Phenotypes of Fl offspring of crosses between M. phyllosomus and M. longipennis - All F1 individuals were morphologically similar to M. longipennis (Table II).

Phenotypes of F2 offspring of crosses between $M$. phyllosomus and M. longipennis - All F2 offspring of crosses (regardless of the species of each parent) displayed morphological characteristics typical of $M$. longipennis (Table III). The previously described fertility test was used to demonstrate that all F2 specimens were fertile.

Non-morphological hybrids of M. phyllosomus and M. longipennis - These hybrids presented a corium lacking an extensive white area, but were primarily black with yellow or orange-red markings basally and subapically (similar to both parents). They also presented a corium with short, slightly decumbent or addressed setae no more than $0.3 \mathrm{~mm}$ long. Their genae did not attain the level of the apex of the clypeus, the posterior lobe of the pronotum was entirely black, dorsal connexival segments were black with yellow or orange-yellow spots on the posterior third or half, extending or not to the connex- ival suture. The mesosternum had long, suberected hairs, and the metasternum and abdominal venter had similar or decumbent hairs (similar to M. longipennis) (Fig. 1).

Phenotypes of F1 offspring of crosses between $M$. phyllosomus and M. picturatus - All F1 individuals, as well as the F1 progeny of backcrosses, were morphologically similar to M. picturatus (Table II).

Phenotypes of F2 offspring of crosses between $M$. phyllosomus and M. picturatus - Two phenotypes ( $M$. phyllosomus and M. picturatus) were obtained from the crosses between ${ }_{+} M$. phyllosomus and ${ }^{\lambda} M$. picturatus, whereas only one phenotype (M. picturatus) was obtained from the inverse crosses (Table III). As described previously, F2 x F2 crosses were conducted and progeny was obtained.

Non-morphological hybrids of M. phyllosomus and M. picturatus - These hybrids presented with a corium lacking an extensive white area and instead were primarily black with yellow or orange-red markings basally and subapically (similar to both parents). Additionally, they presented with a corium with short, slightly decumbent or addressed setae no more than $0.3 \mathrm{~mm}$ long. Their genae attained or surpassed the level of the apex of the clypeus, the posterior lobe of the pronotum was extensively orangeyellow, the dorsal connexival segments were primarily orange-yellow with enterolateral black spots. Mesosternum, metasternum and abdominal venter with long suberected hairs (similar to M. picturatus) (Fig. 1).

Phenotypes of F1 offspring of crosses between $M$. phyllosomus and M. mazzottii - All F1 individuals, as well as the F1 progeny of backcrosses, were morphologically similar to M. mazzottii (Table II).

Phenotypes of F2 offspring of crosses between $M$. phyllosomus and M. mazzottii - All F2 offspring of crosses between M. phyllosomus and M. mazzottii (regardless of the species of each parent) displayed morphological characteristics typical of M. mazzottii (Table III). The previously described fertility test found that all F2 specimens were fertile.

Non-morphological hybrids of M. phyllosomus and M. mazzottii - These hybrids presented with a corium lacking an extensive white area and instead were primarily black with yellow or orange-red markings basally and subapically. They also presented with a corium with long, delicate, suberected hairs, approximately $0.5 \mathrm{~mm}$

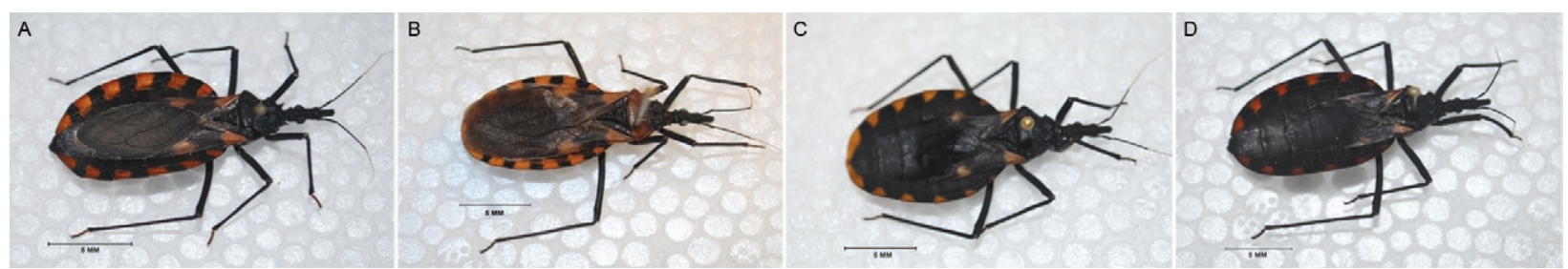

Fig. 1: hybrids from different crosses between species of the genus Meccus: A: Meccus phyllosomus x Meccus mazzottii; B: M. phyllosomus x Meccus picturatus; C: M. phyllosomus x Meccus longipennis; D: M. phyllosomus x Meccus bassolsae. 
long (similar to both parents). They had long hemelytra approaching or extending to the apex of the abdomen and connexivum dorsally with orange-red spots covering the entire posterior third to half of segments (similar to M. mazzottii) (Fig. 1).

Phenotypes of F1 offspring of crosses between $M$. phyllosomus and M. bassolsae - All F1 offspring individuals as well as the F1 progeny of backcrosses had the phenotype of M. phyllosomus (Table II).

Phenotypes of F2 offspring of crosses between $M$. phyllosomus and M. bassolsae - No specimen was obtained (Table III). The same procedure described above was performed, with similar results: all F1 females tested laid fertile eggs from which numerous first in- star nymphs were obtained, while infertile eggs were obtained (in a second step) from backcrosses between F1 males and virgin females of M. phyllosomus, as well as from F1 males and virgin females of M. bassolsae. Finally, all the females used in the fertility test were crossed with parental lineage males. Fertile eggs and first instar nymphs were obtained and these male hybrids were therefore considered to be infertile.

Non-morphological hybrids of M. phyllosomus and M. bassolsae - These hybrids presented with a corium lacking an extensive white area and instead were primarily black with yellow or orange-red markings basally and subapically. Additionally, the corium had long, delicate, erected hairs, about $0.5 \mathrm{~mm}$ long. They had short

\section{TABLE III}

Phenotypes of the second generation derived from crosses between species of the genus Meccus under laboratory conditions

\begin{tabular}{|c|c|c|c|c|c|c|c|c|c|c|c|c|c|}
\hline \multirow[b]{2}{*}{ Crosses } & \multirow[b]{2}{*}{ F1 vs. F1 crosses } & \multicolumn{2}{|c|}{$\begin{array}{c}\text { Meccus } \\
\text { pallidipennis }\end{array}$} & \multicolumn{2}{|c|}{$\begin{array}{c}\text { Meccus } \\
\text { longipennis }\end{array}$} & \multicolumn{2}{|c|}{$\begin{array}{l}\text { Meccus } \\
\text { picturatus }\end{array}$} & \multicolumn{2}{|c|}{$\begin{array}{c}\text { Meccus } \\
\text { mazzottii }\end{array}$} & \multicolumn{2}{|c|}{$\begin{array}{c}\text { Meccus } \\
\text { phyllosomus }\end{array}$} & \multicolumn{2}{|c|}{$\begin{array}{c}\text { Meccus } \\
\text { bassolsae }\end{array}$} \\
\hline & & q & $\hat{\sigma}$ & q & $\hat{o}$ & q & $\hat{\sigma}$ & q & $\hat{\sigma}$ & q & $\hat{\sigma}$ & $q$ & $\hat{\sigma}$ \\
\hline $\begin{array}{l}\text { } M . \text { phyllosomus } x \\
\text { \M. pallidipennis }\end{array}$ & $\begin{array}{l}+M \cdot \text { pallidipennis } x \\
\lesssim M . \text { pallidipennis }\end{array}$ & - & - & - & - & - & - & - & - & - & - & - & - \\
\hline $\begin{array}{l}\text { } M . \text { pallidipennis } x \\
\delta^{\top} \text { M. phyllosomus }\end{array}$ & $\begin{array}{l}+M \cdot \text { pallidipennis } x \\
\lesssim M . \text { pallidipennis }\end{array}$ & - & - & - & - & - & - & - & - & - & - & - & - \\
\hline $\begin{array}{l}\text { } 9 \text { M. phyllosomus } x \\
{ }^{\lambda} M . \text { longipennis }\end{array}$ & $\begin{array}{l}+M . \text { longipennis } x \\
\widehat{\lambda} \text { M. longipennis }\end{array}$ & - & - & 36 & 28 & - & - & - & - & - & - & - & - \\
\hline $\begin{array}{l}\text { } M . \text { longipennis } x \\
\lambda^{M} \cdot \text { phyllosomus }\end{array}$ & $\begin{array}{l}\text { } M . \text { longipennis } x \\
\delta^{\top} M . \text { longipennis }\end{array}$ & - & - & 59 & 58 & - & - & - & - & - & - & - & - \\
\hline $\begin{array}{l}\text { } M \cdot \text { phyllosomus } x \\
\partial^{\uparrow} M \cdot \text { picturatus }\end{array}$ & $\begin{array}{l}\text { +M. picturatus } x \\
\Im M \cdot \text { picturatus }\end{array}$ & - & - & - & - & 59 & 62 & - & - & 63 & 30 & - & - \\
\hline $\begin{array}{l}\text { } M \cdot \text { picturatus } x \\
\partial^{\top} M \cdot \text { phyllosomus }\end{array}$ & $\begin{array}{l}\text { oM. picturatus } x \\
\widehat{\lambda} \cdot \text { picturatus }\end{array}$ & - & - & - & - & 124 & 90 & - & - & - & - & - & - \\
\hline $\begin{array}{l}\text { } M . \text { phyllosomus } x \\
\text { ऽM. mazzottii }\end{array}$ & $\begin{array}{l}+M . \text { mazzottiix } \\
\jmath^{\top} M . \text { mazzottii }\end{array}$ & - & - & - & - & - & - & 57 & 88 & - & - & - & - \\
\hline $\begin{array}{l}\text { QM. mazzottii } x \\
\text { MM. phyllosomus }\end{array}$ & $\begin{array}{l}\text { qM. mazzottii } x \\
\delta^{\lambda} M . \text { mazzottii }\end{array}$ & - & - & - & - & - & - & 154 & 67 & - & - & - & - \\
\hline $\begin{array}{l}\text { } M . \text { phyllosomus } x \\
\text { oM. bassolsae }\end{array}$ & $\begin{array}{l}+M . \text { phyllosomus } x \\
{ }^{\Uparrow} M . \text { phyllosomus }\end{array}$ & - & - & - & - & - & - & - & - & - & - & - & - \\
\hline $\begin{array}{l}\text { †M. bassolsae } x \\
\text { TM. phyllosomus }\end{array}$ & $\begin{array}{l}+M . \text { phyllosomus } x \\
\lesssim M . \text { phyllosomus }\end{array}$ & - & - & - & - & - & - & - & - & - & - & - & - \\
\hline $\begin{array}{l}\text { OM. bassolsae } x \\
\partial^{\top} M . \text { pallidipennis }\end{array}$ & $\begin{array}{l}+M \cdot \text { pallidipennis } x \\
{ }^{\top} M . \text { pallidipennis }\end{array}$ & 302 & 314 & - & - & - & - & - & - & - & - & 82 & 83 \\
\hline \begin{tabular}{l} 
$M$. pallidipennis $x$ \\
\multirow{\partial}{M}{. bassolsae }
\end{tabular} & $\begin{array}{l}+M \cdot \text { pallidipennis } x \\
\lesssim M . \text { pallidipennis }\end{array}$ & 140 & 138 & - & - & - & - & - & - & - & - & 32 & 33 \\
\hline $\begin{array}{l}+M . \text { bassolsae } x \\
{ }^{\top} M . \text { longipennis }\end{array}$ & $\begin{array}{l}\text { oM. longipennis } x \\
\jmath^{M} \text {. longipennis }\end{array}$ & - & - & 186 & 221 & - & - & - & - & - & - & 44 & 33 \\
\hline $\begin{array}{l}+M . \text { longipennis } x \\
\stackrel{+}{\uparrow} \text {. bassolsae }\end{array}$ & $\begin{array}{l}+M . \text { longipennis } x \\
\precsim M . \text { longipennis }\end{array}$ & - & - & 159 & 170 & - & - & - & - & - & - & 74 & 59 \\
\hline \begin{tabular}{l}
$+M$. bassolsae $x$ \\
\multirow{\prime}{\top}{. picturatus }
\end{tabular} & $\begin{array}{l}\text { oM. picturatus } x \\
\Im M \cdot \text { picturatus }\end{array}$ & - & - & - & - & 364 & 343 & - & - & - & - & 105 & 98 \\
\hline $\begin{array}{l}+M . \text { picturatus } x \\
\overbrace{M} \text { bassolsae }\end{array}$ & $\begin{array}{l}\text { oM. picturatus } x \\
\Im M . \text { picturatus }\end{array}$ & - & - & - & - & 325 & 236 & - & - & - & - & 118 & 93 \\
\hline
\end{tabular}


hemelytra truncated uroterguite VI and a connexivum with orange-red spots on each segment (similar to both parents). The anteocular region was 2.5-2.8 times longer than postocular region. The second segment of the rostrum was relatively short (1:1.4:0.5). They had few elevated distal tubercle, few developed lateral tubercle and the antero-lateral angle had few elongations (similar to M. phyllosomus) (Fig. 1).

Phenotypes of F1 offspring of crosses between $M$. bassolsae and M. pallidipennis - All F1 individuals were morphologically similar to M. pallidipennis (Table II).

Phenotypes of F2 offspring of crosses between $M$. bassolsae and M. pallidipennis - Two phenotypes ( $M$. bassolsae and M. pallidipennis) were obtained from crosses between M. bassolsae and M. pallidipennis (Table III). As described previously, F2 x F2 crosses were conducted and progeny was obtained.

Phenotypes of F1 offspring of crosses between M. bassolsae and M. longipennis - All F1 individuals were morphologically similar to M. longipennis (Table II).

Phenotypes of F2 offspring of crosses between $M$. bassolsae and M. longipennis - Two phenotypes ( $M$. bassolsae and M. longipennis) were obtained from the crosses between M. bassolsae and M. longipennis (Table III). As described previously, F2 x F2 crosses were conducted and progeny was obtained.

Phenotypes of F1 offspring of crosses between M. bassolsae and M. picturatus - All F1 individuals were morphologically similar to $M$. picturatus (Table II).

Phenotypes of F2 offspring of crosses between $M$. bassolsae and M. picturatus - Two phenotypes (M. bassolsae and M. picturatus) were obtained from the crosses between M. bassolsae and M. picturatus (Table III). The previously described fertility test demonstrated that all F2 specimens were fertile.

Non-morphological hybrids of M. bassolsae and M. pallidipennis, M. longipennis and M. picturatus These hybrids were similar to the previously described offspring of those sets of crosses of M. phyllosomus and M. pallidipennis, M. longipennis and M. picturatus, respectively (Fig. 1).

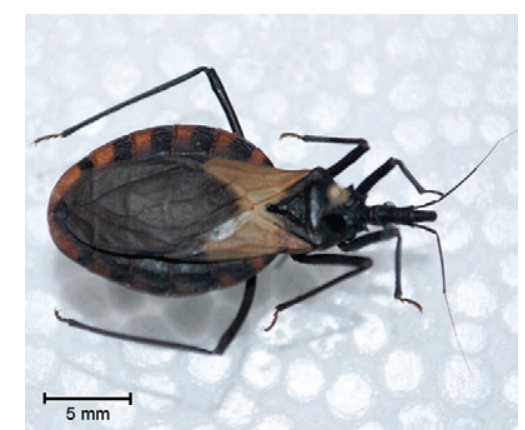

Fig. 2: hybrids from crosses between Meccus phyllosomus x Meccus pallidipennis.

\section{DISCUSSION}

Studies on hybridisation are extraordinarily powerful tools for analysing phenomena that may lead a population to divergence and speciation (for example, the formation of isolating mechanisms). Although the results of experimental crosses under laboratory conditions can be biased when organisms of different species are forced (breaking all ecological, behavioural and geographical barriers) to live together, these kinds of studies may help in understanding the systematics of a group (Pérez et al. 2005).

Success (couples with offspring) in each type of cross appeared not to be correlated to the geographic distance between species collection areas. Similar results were obtained when M. mazzottii were crossed with specimens of the other four species of the Phyllosoma group, with the exception of M. bassolsae (Martínez-Ibarra et al. 2008b).

Nearly all F1 offspring of crosses involving M. phyllosomus, with the exception of crosses for M. bassolsae and nearly all obtained specimens of the second generation displayed most of the typical characteristics of those four species (M. pallidipennis, M. longipennis, M. picturatus and M. mazzottii). Similarly, all F1 offspring of crosses involving M. bassolsae and most specimens of the second generation displayed most of the typical characteristics of the four species (M. pallidipennis, M. longipennis, M. picturatus and M. phyllosomus) crossed with it, as did previously reported specimens resulting from crosses between M. bassolsae and M. mazzottii (Martínez-Ibarra et al. 2008b). Apparently, most M. phyllosomus and M. bassolsae alleles (particularly those for size, overall colour and hair type and size) have Mendelian dominant/recessive relationships with the corresponding alleles of some species in this study, such as M. pallidipennis, M. longipennis, M. picturatus and M. phyllosomus.

A low percentage of successful crosses was recorded in most F1 x F1 crosses where M. phyllosomus was involved. The offspring (second generation) was scarce in the majority of these crosses and was null in those sets of crosses for M. pallidipennis and M. bassolsae. These results indicate the significant reproductive isolation of those offspring, with the results that these hybrids would have little chance of perpetuating themselves. Similar results were recorded when $M$. mazzottii was crossed with M. longipennis, M. pallidipennis, M. picturatus and $M$. bassolsae (Martínez-Ibarra et al. 2008b). Our findings support a model in which different degrees of reproductive isolation exist among the species of Meccus involved in this study, and M. phyllosomus is more reproductively isolated from the other five species of Meccus than is $M$. bassolsae. These results are in agreement with a previous study (Martínez-Ibarra et al. 2008b), where M. mazzottii was reproductively isolated from the four species of Meccus examined (M. phyllosomus was not included in that study). Our results, in combination with results showing little or no genetic differences between these species (Bargues et al. 2008) indicate that these species are closely related and have diverged very recently.

Our study supports the proposition that crossbreeding played an important role in the origin and diversification of the triatomine species, as has been suggested 
for Triatoma brasiliensis Neiva (Costa et al. 2009) and for M. pallidipennis, M. longipennis and M. picturatus (Martínez et al. 2010).

According to the biological species concept, "a species is a group of interbreeding natural populations that is reproductively isolated from other such groups" (Mayr \& Ashlock 1991). However, "subspecies are local populations that are recognisably different from each other but they are nevertheless considered to belong to the same species, because they are observed to interbreed in nature or because it is inferred that they are likely to interbreed" (Mayr \& Diamond 2001). In accordance with these species and subspecies concepts and in light of some previously published reports (Flores et al. 2001, Martínez et al. 2005, 2006, 2010, Takashi-Obara et al. 2007, Bargues et al. 2008), the biological evidence reported here supports the proposition that it is more appropriate to attribute a subspecies level to M. bassolsae, as has been proposed for M. pallidipennis, M. longipennis and M. picturatus (Martínez-Ibarra et al. 2008b, 2009). However, the same biological evidence supports the proposal that M. phyllosomus is a full species, as some recent molecular studies have proposed (Sainz et al. 2004, Pfeiler et al. 2006).

\section{ACKNOWLEDGMENTS}

To Jorge Martínez-Grant and Monserrat Martínez-Grant, for helping in the development of this study, and to Jorge Martínez-Ibarra, for helping on take the pictures of triatomines.

\section{REFERENCES}

Bargues MD, Klisiowicz DR, González-Candelas F, Ramsey JM, Monroy C, Ponce C, Salazar-Schettino PM, Panzera F, Abad-Franch F, Souza OE, Schofield CJ, Dujardin JP, Guhl F, Mas-Coma S 2008. Phylogeography and genetic variation of Triatoma dimidiata, the main Chagas disease vector in Central America and its position within the genus Triatoma. PLos Negl Trop Dis 2: e233.

Carcavallo R, Jurberg J, Lent H, Noireau F, Galvão C 2000. Phylogeny of the Triatominae (Hemiptera: Reduviidae). Proposal for taxonomic arrangements. Entomol Vect 7: 1-99.

Costa J, Peterson TA, Dujardin JP 2009. Morphological evidence suggests homoploid hybridization as a possible mode of speciation in the Triatominae (Hemiptera, Heteroptera, Reduviidae). Infect Genet Evol 9: 263-270.

Flores A, Magallón-Gastélum E, Bosseno MF, Ordóñez R, LozanoKasten F, Espinoza B, Ramsey JM, Breniere SF 2001. Isoenzyme variability of five principal triatomine vector species of Chagas disease in Mexico. Infect Genet Evol 4: 1-8.

Lent H, Wygodzinsky P 1979. Revision of the triatominae (Hemiptera: Reduviidae) and their significance as vectors of Chagas disease. Bull Am Mus Nat Hist 163: 123-520.

Licón-Trillo A, Balsimelli-De La Peña K, Acosta-Legarda M, LealSolís I, Nogueda-Torres B, Martínez-Ibarra JA 2010. Infección natural por Trypanosoma cruzi en triatominos del Centro y Norte de México. Bol Mal Salud Amb 50: 91-93.

Marcilla A, Bargues MD, Ramsey JM, Magallón-Gastélum E, Salazar-Schettino PM, Abad-Franch F, Dujardin JP, Schofied CJ, Mas-Coma S 2001. The ITS-2 of the nuclear rDNA as a molecular marker for populations, species and phylogenetic relationships in Triatominae (Hemiptera: Reduviidae), vector of Chagas disease. Mol Phylogenet Evol 18: 136-142.
Martínez F, Alejandre-Aguilar R, Hortelano-Moncada Y, Espinoza B 2005. Molecular taxonomic study of Chagas disease vectors from the Phyllosoma, Lecticularia and Rubrofasciata complexes. $\mathrm{Am}$ J Trop Med Hyg 73: 321-325.

Martínez F, Martínez-Ibarra JA, Catalá S, Villalobos G, de la Torre P, Laclette J, Alejandre-Aguilar R, Espinoza B 2010. Natural crossbreeding between sympatric species of the Phyllosoma complex (Insecta: Hemiptera: Reduviidae) indicate the existence of only one species with morphologic and genetic variations. Am J Trop Med Hyg 82: 74-82.

Martínez HF, Villalobos CG, Ceballos AM, De la Torre P, Laclette JP, Alejandre-Aguilar R, Espinoza B 2006. Phylogenetic analysis of Triatominae (Hemiptera: Reduviidae) species of epidemiological importance in the transmission of Chagas disease: nuclear DNA vs. mitochondrial DNA as molecular markers. Mol Phylogenet Evol 41: 279-287.

Martínez-Ibarra JA, Alejandre-Aguilar R, Torres-Morales A, Trujillo-García JC, Nogueda-Torres B, Trujillo-Contreras F 2006. Biology of three species of the Meccus phyllosomus complex (Hemiptera: Reduviidae: Triatominae) fed on blood of hens and rabbits. Mem Inst Oswaldo Cruz 101: 787-794.

Martínez-Ibarra JA, Grant-Guillén Y, Martínez-Grant DM 2003a. Feeding, defecation and development times of Meccus longipennis Usinger, 1939 (Hemiptera: Reduviidae: Triatominae) under laboratory conditions. Mem Inst Oswaldo Cruz 98: 899-903.

Martínez-Ibarra JA, Grant-Guillén Y, Morales-Corona ZY, HaroRodriguez S, Ventura-Rodríguez LV, Nogueda-Torres B, BustosSaldaña R 2008a. Importance of species of Triatominae (Heteroptera: Reduviidae) in the risk of transmission of Trypanosoma cruzi in western Mexico. J Med Entomol 45: 476-482.

Martínez-Ibarra JA, Martínez-Grant JA, Verdugo-Cervantes MR, Bustos-Saldaña R, Nogueda-Torres B 2010. Monitoreo de la presencia de triatominos mediante gallineros en el sur de Jalisco, México. Biomedica 30: 140-145.

Martínez-Ibarra JA, Novelo-López M 2004. Biological parameters of Meccus pallidipennis Stål (Hemiptera: Reduviidae) under laboratory conditions. Folia Entomol Mex 43: 313-319.

Martínez-Ibarra JA, Novelo-López M, Hernández-Robles MR, GrantGuillén Y 2003b. Influence of the blood meal source on the biology of Meccus picturatus Usinger 1939 (Hemiptera: Reduviidae: Triatominae) under laboratory conditions. Mem Inst Oswaldo Cruz 98: 227-232.

Martínez-Ibarra JA, Salazar-Schettino PM, Nogueda-Torres B, Vences MO, Tapia-González JM, Espinoza-Gutiérrez B 2009. Occurrence of hybrids and laboratory evidence of fertility among three species of the Phyllosoma complex (Hemiptera: Reduviidae) in Mexico. Mem Inst Oswaldo Cruz 104: 1125-1131.

Martínez-Ibarra JA, Ventura-Rodríguez LV, Meillon K, BarajasMartínez HM, Alejandre-Aguilar R, Lupercio-Coronel P, RochaChávez G, Nogueda-Torres B 2008b. Biological and genetic aspects of crosses between species of the Phyllosoma complex (Hemiptera: Reduviidae: Triatominae). Mem Inst Oswaldo Cruz 103: 236-243.

Mayr E, Ashlock PD 1991. Principles of systematic zoology, McGrawHill, New York, 475 pp.

Mayr E, Diamond J 2001. The birds of northern Melanesia, Oxford University Press, Oxford, $492 \mathrm{pp}$.

Mazzotti L, Osorio MT 1942. Cruzamientos experimentales entre varias especies de triatomas. Rev Mex Med 22: 215-222.

Medina-Torres I, Vázquez-Chagoyán JC, Rodríguez-Vivas RI, Montes de Oca-Jiménez R 2010. Risk factors associated with triato- 
mines and its infection with Trypanosoma cruzi in rural communities from southern region of the state of Mexico, Mexico. Am J Trop Med Hyg 82: 49-54.

Pérez R, Hernández M, Quintero O, Scvortzoff E, Canale D, Méndez L, Cohanoff C, Martino M, Panzera F 2005. Cytogenetic analysis of experimental hybrids in species of Triatominae (HemipteraReduviidae). Genetica 125: 261-270.

Pfeiler E, Bitler BG, Ramsey JM, Palacios-Cardiel C, Markow TA 2006. Genetic variation, population structure and phylogenetic relationships of Triatoma rubida and T. recurva (Hemiptera: Reduviidae: Triatominae) from the Sonoran desert, insect vectors of the Chagas' disease parasite Trypanosoma cruzi. Mol Phylogenet Evol 41: 209-221.
Rodríguez-Bataz E, Nogueda-Torres B, Rosario-Cruz R, MartínezIbarra JA, Rosas-Acevedo JL 2011. Triatominos (Hemiptera: Reduviidae) vectores de Trypanosoma cruzi Chagas, 1909 en el estado de Guerrero, México. Rev Biomed, in press.

Sainz AC, Mauro LV, Moriyama EN, García BA 2004. Phylogeny of triatomine vectors of Trypanosoma cruzi suggested by mithocondrial DNA sequences. Genetica 121: 229-240.

Southwood TRE, Henderson PA 2000. Ecological methods, Blackwell Science, Oxford, $575 \mathrm{pp}$.

Takashi-Obara M, Soares-Barata JM, Nunes da Silva N, CerettiJúnior W, Urbinatti PR, da Rosa JA, Jurberg J, Galvão C 2007. Estudo do ovos de quarto espécies do gênero Meccus (Hemiptera, Reduviidae, Triatominae), vetores da doença de Chagas. Mem Inst Oswaldo Cruz 102: 13-19. 